\title{
Developing network insight
}

\author{
Stefanos Mouzas ${ }^{a, *}$, Stephan Henneberg ${ }^{b, 1}$, Peter Naudé ${ }^{b, 2}$ \\ ${ }^{a}$ Lancaster University, Management School, Lancaster LA1 4YW, United Kingdom \\ ${ }^{\mathrm{b}}$ Manchester Business School, The University of Manchester, Booth Street West, Manchester M15 6PB, United Kingdom
}

Received 1 January 2005; received in revised form 1 July 2006; accepted 1 January 2007

Available online 22 February 2007

\begin{abstract}
A challenge facing organizations is that of amalgamating possibilities which do not exist in a transparent and concentrated form, but rather as dispersed individual cognitive 'pictures' perceived by managers embedded in business networks. Based on our research of business networks involving manufacturers of consumer goods, pharmaceutical companies, producers of semiconductors and telecommunication and utility service providers, we propose the concept of network insight, which does not consist merely of extant pictures held by individual managers, but is grounded in the practice of inter-firm exchange. We argue that developing network insight is a managerial challenge encompassing the amalgamation of dispersed pieces of atomized network pictures through heedful, multilateral interactions. Such a managerial activity transcends the task-specific knowledge base of managerial cognition and leads to objectified organizational learning within a business network. Managers that develop insight in business networks are able to mobilize other actors and create a competitive advantage for their organization that is crucial for innovation and growth.
\end{abstract}

(C) 2007 Elsevier Inc. All rights reserved.

Keywords: Cognition; Sense-making; Representations; Insight; Networks

\section{The problem of developing network insight}

It is commonly argued that business networks that include organizations of different types, in general provide the relevant context for organizational practice (Anderson, Håkansson, \& Johanson, 1994; Uzzi, 1997; Uzzi \& Lancaster, 2003) and marketing in particular (Achrol, 1997; Achrol \& Kotler, 1999). The challenge that companies face within these 'communities of practice' when strategizing (Gadde, Huemer, \& Håkansson, 2003) consists of amalgamating the possibilities for action; all of which do not exist in a transparent and concentrated form, but solely as dispersed individual cognitive 'pictures' held by managers who are in a network. These atomized and often contradictory 'network pictures' (Ford, Gadde, Hakansson, \& Snehota, 2003; Henneberg, Mouzas, \& Naudé, 2006) refer to their extant understanding that different managers have of

\footnotetext{
* Corresponding author. Tel.: +44 7766645275.

E-mail addresses: S.Mouzas@lancaster.ac.uk (S. Mouzas), Stephan.Henneberg@mbs.ac.uk (S. Henneberg), Peter.Naude@mbs.ac.uk (P. Naudé).

${ }^{1}$ Tel.: +441613063463.

2 Tel.: +44 1612757782 .
}

surrounding networks in terms of actors, interactions, and means-end relationships (Hodgkinson \& Johnson, 1994; Johnson, Daniels, \& Asch, 1998; Smircich \& Stubbart, 1985). Network pictures can, therefore, be given realist status akin to 'extant knowledge'. Extant experiences, for example, enable actors to select certain aspects from the flow of events and build categories or schemata of understanding (Hodgkinson, 2001; Weick, 1979). One would be tempted to rush into a straightforward response to the challenge of integrating these individually held network pictures, by claiming that managers need to search for several individual pictures and compare them by using complementary elements in order to form an integrated perspective. This, however, is not sufficient. Networking (Ford et al., 2003) within communities of practice does not flow directly out of a multitude of network pictures but requires further interactions and exchange processes before insights are gained (Tsoukas, 2000). Consider a business manager who investigates entry into a new business network. The network pictures that he may obtain regarding customers' issues and competitive dynamics are, arguably, useful first impressions. However, can he be sure ab.out the underlying logic and interests of his customers? Can he rely on the views that he obtained without any 
prior exchanges in the network that he intends to enter? Consider also a business manager who finally closes a business deal by taking into account all important task-specific requirements. Is this deal the best possible solution for both parties? Or does the manager leave riches on the negotiation table by ignoring nontask related interests of the other contracting party? Is a business deal sustainable if it is based on a thorough investigation and comparison of a multitude of individual cognitive 'pictures' held by business actors? It is these types of questions that underpin the problem of developing network insight.

There are two reasons why further interactions and exchange processes are needed in order to address the challenge of amalgamating dispersed cognitive pictures in a business network. Firstly, managers' cognitive pictures are continually re-configured to resolve inherent conflicts and exploit opportunities through activities and negotiations undertaken by the organizations in their intermediate network. Moreover, cognitive pictures impact on each other at different levels: at the individual 'carrier' level, invariably at the level of an individual manager in a management team, at the intra-company relationship level between individuals in management teams, and at the inter-company network level (Lyles \& Schwenk, 1992). Thus, organizations cannot fully construct and explain in advance all individual views held by other actors, nor can these views be anticipated to be stable. Secondly, differential knowledge for positioning and acting within a network which is the basis for organizations' innovative action is not self-contained in network pictures, but emerge as a set of possibilities through enacted tensions and the formation of discrepancies. Clearly, possibilities are not engrained in cognitive representations. Instead, they 'develop' as strategic options and need to be elaborated through interactions and specific exchange activities (Beinhocker, 1999; Luehman, 1998; McGrath, Ferrier, \& Mendelow, 2004; Williamson, 1999).

While optimization through adding and comparing individual cognitive 'pictures' is less helpful, many organizations rely on the implicit importance of rules which include a set of methods, standards or routines (March \& Olsen, 1989; March \& Simon, 1993). A set of managerial methods may help to overcome the problems of individually held network pictures, such as those described above. For this reason, we propose managerial methods to develop insight in business networks, which does not merely consist of the pictures of individual players but comprises objectified knowledge for positioning and acting. We characterize network insight as 'objectified' because it consists of a set of shared data, information or facts. Network insight can be seen as the outcome of continuous and iterative interplay between the factual physical and social artifacts that surround actors in networks of exchange relationships as well as the cognitive schemata constructed and shaped from actors' past experience and precedents. We have chosen the title developing network insight deliberately to emphasize the inherently developmental and indeterminate nature of the 'network insight'. Each inter-organizational network consists of pre-existing interaction and exchange relationships and evolutionary dynamics that continually reshape what is feasible and what is successful. Through the construct of 'network insight' we describe the emergence of a set of possibilities open to each organization within that network; and argue that network insight can lead to a competitive advantage within a business network as well as for the business network itself. This paper presents a procedural map for developing insight to business networks. We describe the amalgamation process of individual, cognitive pictures as the basis on which managers can step aside from extant knowledge in order to develop an objectified narrative and assessment of the situation in which they are embedded. We then analyze important enablers and barriers to developing network insight. We argue that developing network insight is a managerial challenge that requires the ability to cope with the complexities of a) multilateral exchange, b) manifold rationalities, and c) recursive time. We then move on to illustrate via two cases the inherent difficulties of companies developing network insight. The first case represents successful management of the process of developing network insight, while the second exemplifies inherent errors and deficiencies. We finally present conclusions and guiding principles for business managers and management teams.

\section{Previous research: three management perspectives}

We now present previous research organized via three perspectives: 1) networks, 2) knowledge and 3) collective mind. Theoretical ideas contained in these three perspectives are abstract, interrelated and, often, overlapping or contradictory assertions. We summarize their relevant input (without necessarily always resolving their contradictions) in terms of conceptual tools and move on to propose a framework that illustrates the process of amalgamating dispersed network pictures into network insight.

\subsection{Network perspective}

The network perspective is entrenched in the recognition of markets as networks of exchange relationships (Axelsson, 1992; Dyer \& Singh, 1998; Gnyawali \& Madhavan, 2001; Halinen, Salmi, \& Havila, 1999; Kranton \& Minehart, 2001; Stevenson \& Greenberg, 2000). The view of markets as interconnected networks of exchange relationships prompted a whole generation of researchers to analyze and describe the characteristics of these networks (Ford, 1998; Anderson et al., 1994; Easton, 1992; Easton \& Håkansson, 1996; Ford et al., 2003; Håkansson \& Snehota, 1994; Håkansson \& Ford, 2002; Ritter, 1999; Turnbull, Ford, \& Cunningham, 1996; Wilkinson \& Young, 2002). Network pictures are a central concept to the network perspective. They describe the mental representations, or cognitive maps, of relevant network characteristics as internalized through the eyes of involved actors (Bougon, Weick, \& Binkhorst, 1977; Huff, 1990; Ford et al., 2003). The attempt to portray network characteristics and provide a plausible narrative for past events, current positions and future developments, can be traced back to Johanson and Mattsson's (1992) 'network theory'. Network pictures are the actor's 'network theory' (Mattsson, 2002b). As with Weick's (1995) notion of sense-making, network pictures are actively contributing to the 
process of organizations' and network's identity construction through individual sense-making and representational processes (Holmen \& Pedersen, 2003). Network pictures are retrospective in the sense that they provide a plausible representation of recent-past events and current positions; yet also offer prospective in that they shape organizations' future options (Weick, 1979, 1988).

Notwithstanding the intellectual debate regarding network pictures (as well as related discussions in the strategy literature about competitive groups and also cognitive maps in the organizational behavior literature) (Bogner \& Thomas, 1993; Bougon, 1992; Bougon et al., 1977; Daft \& Weick, 1984; Daniels, Johnson, \& de Chernatony, 2002; de Chernatony, Daniels, \& Johnson, 1993; Eden, Ackermann, \& Cropper, 1992; Fiol \& Huff, 1992; Hodgkinson, 1997; Hodgkinson \& Johnson, 1994; Huff, 1997, 1990; Osborne, Stubbart, \& Ramaprasad, 2001; Porac, Thomas, \& Baden-Fuller, 1989; Stubbart, 1989; Spender, 1998), there have been few attempts to rigorously conceptualize the underlying dimensions of such network representations and to test their applicability in the authentic life of organizations (Cova, Mazet, \& Salle, 1998) or to link their characteristics to performance outcomes (McNamara, Deephouse, \& Luce et al., 2003; McNamara, Luce, \& Tompson et al., 2002). There are ample attempts in related areas such as the work on constructed and emergent elements of sense-making that provide valuable input (Hodgkinson, 2001). Henneberg et al. (2006) provide an extensive review of previous work on network pictures in the business-to-business marketing literature and propose a parsimonious set of eight interrelated dimensions. Their study demonstrates that the utilization of the different dimensions is primarily determined by what it is that managers wish to represent, within a specific task-oriented environment. As there is no definitive notion of abstract or 'correct' network picture, Ford et al. (2003) argue that the different managers involved will naturally have their own individual views. These individual cognitive representations matter as they provide the foundation for organizational activity, yet they do so without reifying the organization as an 'actor' (Meindl, Stubbart, \& Porac, 1994). Managers' cognitive representations of the network and its characteristics can be seen as embracing an individual's 'frame of reference', including cognitive limitations. It could, therefore, be argued that network pictures describe a specific and limiting framework of bounded rationality (Simon, 1976, 1979) which prevents the individual actors from knowing all network possibilities, or remembering all previous solutions or spending time and resources to perform complex but necessary calculations with regard to all available options (Simon, 1991; Witt, 2000). Therefore, it can be posited, in line with Simon (1976), that as soon as managers pass a 'satisfycing' threshold of sense-making in networks, they rely on the resultant network pictures and stop their attempt to attain further optimization. The concept of 'satisfycing' may also be linked to the notion of 'aspiration level' in cognitive psychology, which describes a coping strategy that is easier to carry out than continuous and complex processes of optimization (Simon, 1997). This is clearly evident in many managerial decisions within the network context, such as entering, launching or re- launching a new product or service; or entering a new market where many contextual variables are not known or difficult to estimate. Simon (1997) argues that the notion of satisfycing must be connected to the notion of search. In this way 'search' for information or solutions ceases as the satisfycing level is achieved. Simon (1979), of course, did not refer to any idea of sense-making. In theoretical terms, 'sense-making' unlike 'search' is generally conceived as a continuous accomplishment and emergence. Although sense-making is never completed, this does not imply that sense, made at a certain time, does not de facto serve as the basis of action. Confronted with incomplete information, managers may pass the satisfycing threshold because of the existence of a) 'cost rationality' which involves the cost of further observation, communication or calculation, and b) 'truly bounded rationality' which refers to "not knowing the implications of everything one knows" (Radner, 1996, p.1360); managers may also pass the satisfycing threshold because of an inherent 'indeterminacy' that implies a multiplicity of solutions.

What managers therefore need is a coherent framework of methods or processes to overcome these problems. Managers need to integrate their bounded and diverse cognitive pictures for organizational purposes because organizations act as a single entity, and business-to-business relationships can only prosper once congruent 'network identities' at an organizational level have been accomplished (Ring \& van de Ven, 1994). This managerial need shares similarities with the concept of 'network capability' (Eisenhardt \& Martin, 2000; Ritter, Wilkinson, \& Johnston, 2002) which refers to the capability that allows groups, individual companies or whole business networks to comprehend complex situational demands such as unexpected events that evolve rapidly. This capability is characterized by an objectified 'boundedness', i.e. it is not resultant merely from individual bounded rationalities but provides a means to pushing the collective boundaries of sense-making into an interactive realm.

One way to overcome the problem of congruence and integration of individual cognitive pictures is to follow Anderson et al.'s (1994) suggestion that multiple network pictures need to be collected in a more systematic and possibly longitudinal fashion. Their suggestion is to use case studies that capture longer time periods and gather material from different functions, both within an organization and from different organizations. However, they do not indicate a process or theoretical mechanism of how this multiplicity is useful and how it could be used for strategizing (Ford, McDowell, \& Tomkins, 1998). Organizational theory recommends 'merging', 'overlaying' or 'congregating' multiple cognitive maps (Bougon, 1992; Eden, 1989; Eden, Jones, \& Sims, 1983), but again without procedural indication of what this implies. Similarly, other empirical studies highlight the importance for managers to understand the ways or processes of sense-making (Hodgkinson, 2001) in relation to their interaction and exchange activities. In this way, the debate concerning sense-making as a process rather than product in organizational theory (Czarniawska, 2004; Jeffcutt, 1994) reinforces the argument for the use of case studies to investigate the development of network insight because the use of a case-based method can address interaction and exchange 
episodes among actors. We posit that the problem with the active use of network pictures is not simply a matter of numerical sufficiency. Network pictures are atomized constructions that are inferred and interpreted from a variety of cues rather than objectively given. All elements of network pictures imply extant knowledge linked to the tasks at hand that shape individual managers' perceptions (Anderson et al., 1994; Daniels et al., 2002; Möller \& Halinen, 1999). They can be interpreted as a sign of what individual managers' sense is important for them and their organization, but not as a signal germane to the development of 'network competences' or an abstract grasp of network properties or additional abstract strategic network options (Ritter, 1999, 2000). Due to their individual character, network pictures are a personal interpretation of the network context (Mattsson, 2002b; Gadde et al., 2003). Moreover, network pictures are enacted in the sense that existing business networks are interpreted and constructed by the organizations' own initiatives. Their properties are actorcentered as they comprise elements such as the network horizon (Holmen \& Pedersen, 2003) or boundary, centrality, distance, actor, relevance information flow and exchange relationships (Henneberg et al., 2006; McLoughlin \& Horan, 2000). At the same time, the theoretical discussion of network pictures obscures one important point. Namely, there is a significant difference between what is factually possible in a network and what is conceivable by an organization or individual using their specific network pictures. Concepts such as those of network pictures, which ignore this distinction, are unsuitable for bounding a framework that explains and improves practice. To be useful to managers, a theoretical construction needs to be grounded in a deep understanding of the practice of interorganizational exchange (Biggart \& Delbridge, 2004). Network pictures alone are insufficient for organizational practice, in the sense of providing differential advantages. Managers who rely on their individual network pictures might be blinkered. As atomized constructs, managers' network pictures have not been tested within inter-organizational exchange processes, nor have they been linked to cognitive processes (Meindl et al., 1994). They constitute ad-hoc theorizing on cognitive structure that may be removed from reality. While network pictures are undeniably valuable as formulators of organizations' identity construction, their appropriateness for a thorough understanding of networks and strategic networking remains limited. As cognitive representations, network pictures need proper 'translation' through several stages of inter-organizational exchanges before they become amalgamated and, as such, 'objectified' (Mattsson, 2002a, 2003).

\subsection{Knowledge perspective}

While the network perspective qualifies our understanding of cognitive representational constructs resembling network pictures, we need to explore the knowledge perspective to understand the components of network insight. Developing a knowledge approach to economic problems, Hayek (1945) articulated in a forceful and clear way the idea that the economic problem in a society is in fact a problem of the utilization of knowledge not given to anyone in its totality. Hayek formulated this problem in the following way:

"The peculiar character of the problem of rational economic order is determined precisely by the fact that knowledge of circumstances of which we must make use never exists in concentrated or integrated form, but solely as dispersed bits of incomplete and frequently contradictory knowledge which all separate individuals possess. The economic problem of society is thus not merely a problem of how to allocate given resources. It is rather a problem of how to secure the best use of resources known to any of the members of society, for ends whose relative importance only these individuals know" (1945, p. 519).

Developing the macro-realities of a whole society, to the realities of individual firms, Tsoukas (1996) paraphrased Hayek's problem by stating that “...the organizational problem firms' face is the utilization of knowledge which is not, and cannot be, known by a single agent" (p. 11). This agent might be within or outside the borders of the company. In an attempt to refine the view of what organizations constitute, Tsoukas (1996). considers organizations as being in constant flux, and argues that at any point in time, a firm's knowledge is the indeterminate outcome of actors attempting to manage the inevitable tensions between a) normative expectations, b) dispositions from the past and c) local contexts. The consequence of these tensions is that the potential for the emergence of novel practices is never exhausted. Normative expectations, for example, could take the form of roles; but also the form of internal or external pressures to act in a certain way, or indeed of task-related contingencies. Dispositions include sedimented experience; but also the various form such as plans, reviews, statistics and maps/matrices in which information appears. Moreover, local context comprises all specific space-temporal conditions such as the maturity of industry, existing organizational and inter-organizational structures as well as access to the right people at the right time. Building on Giddens' (1984) duality between structure and action, Hargadon and Fanelli (2002). suggest that organizational knowledge is the product of an on-going and recursive interaction between knowledge, as empirical action, and knowledge as a possibility. In their view, knowledge as action encompasses the factual physical and social artifacts that surround actors in organizations, while knowledge as a possibility comprises the schemata constructed and shaped from actors' past experiences. The duality implies that actors' knowledge of action is experienced through the lens of existing cognitive schemata. Hargadon and Fanelli (2002) conclude that the generation of new knowledge or successful replication of old knowledge depends on the cyclic interaction between the 'matter' of the knowledge as an action and the 'energy' that resides in knowledge as a possibility.

Our knowledge may be linked to various objects; for example, objects may be simple or complex, social or material, abstract or concrete, and are characterized by their relations. However "... neither objects nor their relations are given to us transparently: their identification is an achievement and must be worked for" (Sayer, 1984, p.88). Therefore, our knowledge 
claims must be "... evaluated and tested to determine the extent to which they do, or do not, truly represent or correspond to the world" (Hunt, 1990, p. 11). While the knowledge perspective emphasizes the inherently imprecise and indeterminate nature of knowledge, the contemporary management literature is rich with examples of how business opportunities emerged as a byproduct of actions with a different purpose, rather than as intended outcomes of deliberate views and choices (Mintzberg, 1979; Mintzberg \& Waters, 1985). One explanation for these empirical findings is that business opportunities, which organizations exploit, can only be identified if organizations are specifically prepared for them (Denrell, Fang, \& Winter, 2003). It appears, however, that this line of argument misses a crucial attribute of this 'achievement' or 'preparation' process. The challenge of embracing the new business opportunities, which are dispersed in an organization's surrounding network, requires a deep insight into what is feasible. This insight is grounded in the inherent negotiations and interactions in a business network; which are regarded as managerial activities embedded in exchanges (Spender, 1998). A 'preparation process' is particularly useful in knowledge-intensive exchanges where the institutionalization of cognitive frameworks, in the sense of shared mindsets, provides the 'architecture' for on-going and regular exchanges (Boisot, 1995; Karamanos, 2003). This 'architecture' can be compared to discursive institutions which codify the parties' knowledge about efficient ways to interact and transform transactions into discussions "... by which parties come to reinterpret themselves and their relation to each other by elaborating a common understanding of the world" (Sabel, 1994, p. 138).

\subsection{Collective mind perspective}

In order to fully comprehend the notion of insight in business networks and the process of achieving it, a deeper understanding of its characteristics is needed. Research into managerial cognition in the organizational behavior literature can provide a valuable contribution. Such benefits can be gained if we consider specifically the process of achieving 'collective' Collective mind is taken as a construct of integration through interaction. Interaction among actors transfers knowledge and hence alters the actors' minds. This is not fully represented in one person but 'collective' and, therefore, it is partially overlapping between individuals while only partially developed in each individual (Wiley, 1988; Weick \& Roberts, 1993). The idea of collective mind is not fully integrated in Weick's work on 'sense-making' (e.g. Weick, 1993, 1995); nonetheless it can be used as a pointer to the process of successful amalgamation of individual cognitive pictures. In this way, the idea collective mind shares some similarities with the theoretical construct of 'common knowledge' (Grant, 1996; Grant \& Baden-Fuller, 2004). The integration of dispersed cognitive pictures into 'common knowledge' can be seen as the product of continuous and iterative interplay between the factual physical and social artifacts that surround actors in organizations and the cognitive schemata constructed and shaped from actors' past experiences and precedents Hargadon and Fanelli (2002). Thus, in terms of individual cognitive 'pictures' held by managers, these are amalgamated through interactions within and between organizations into a collective understanding of the network: that is, the 'insight'. Whilst mutually shared fields of representation exist (Asch, 1952), this notion of network insight, understood as the collective mind, introduces the possibility that simple actors can comprehend highly complex environments that encompass embedded strategic options. Interrelations are crucial for this purpose because the 'mind' or 'insight' is located in the connections between business actors. Consequently, individual actors can only build collective mind via the interrelation with other actors. Network insight can therefore be termed to be 'social'; and as such it is not stable but changes incrementally with further interrelations; it is collective but not reified (Weick \& Roberts, 1993). The process of achieving 'collective mind' via heedful interactions will be elaborated upon below.

While describing network insight as a sense-making capacity within an on-going system of interactions, this does not clarify how it is procedurally achieved. It begs the question of what kind of interactions foster insight in business networks? How are individual cognitive 'pictures' that are held by managers transformed into 'insights'? Taking our cues again from the notion of a 'collective mind', it follows that the transformation process as an amalgamation of network pictures is linked to the 'heed', expressed in the interrelation activities, e.g. negotiations (Ryle, 1949). Heed is defined as a "disposition to act with attentiveness, alertness, and care" (Weick \& Roberts, 1993, p. 374). Heedful interactions cause the actors to be tightly coupled. They are characterized by rich and manifold connections between actors of all levels within the network system. Long-time horizons for interactions that are concerned with prospective as well as retrospective activities, rich interactions between hierarchies and functions beyond mere task-specific contact, and an integration of manifold levels of experiences within each of the interactions are elements of heedful processes fostering the collective mind. Stress is put on the coordination of actions (not necessarily on cognitive alignment); although respect and trust being more important than agreement per se. Heedful interactions acknowledge diversity as a positive element in creating collective mind situations (Weick \& Roberts, 1993). Specific emphasis is on 'actions' as the starting point for "higher-order pattern[s]" (Weick \& Roberts, 1993, p. 374). These actions of communication and information exchange make tacit assumptions explicit or, as Weick and Roberts (1993) argue, an integration of feeling, thinking, and willing between individuals that allows for a qualitatively new (i.e. objectified) boundedness to coalesce.

Table 1 summarizes the relevant theoretical input from the three theoretical perspectives which are used as conceptual tools in our attempt to describe the process of developing network insight, and to analyze our empirical data.

\section{Network insight: managing the amalgamation process}

Having reviewed the theoretical foundation of this study, we now define the underlying principles and describe managerial 
Table 1

Input from the three management perspectives

\begin{tabular}{|c|c|c|}
\hline Network & Knowledge & Collective mind \\
\hline $\begin{array}{l}\text { Markets are seen as } \\
\text { networks of actors }\end{array}$ & $\begin{array}{l}\text { Knowledge is seen as an } \\
\text { achievement that needs } \\
\text { to be worked for }\end{array}$ & $\begin{array}{l}\text { Collective mind is seen } \\
\text { as an on-going process }\end{array}$ \\
\hline $\begin{array}{l}\text { Cognition evolves within } \\
\text { networks }\end{array}$ & $\begin{array}{l}\text { Knowledge is dispersed } \\
\text { and often contradictory }\end{array}$ & $\begin{array}{l}\text { Heedful interactions as } \\
\text { foundation }\end{array}$ \\
\hline $\begin{array}{l}\text { Network view shapes } \\
\text { actors' identities }\end{array}$ & $\begin{array}{l}\text { Three enacted tensions } \\
\text { need to be managed: }\end{array}$ & $\begin{array}{l}\text { Collective mind starts } \\
\text { with action before it } \\
\text { becomes capacity }\end{array}$ \\
\hline $\begin{array}{l}\text { Exchange relationships } \\
\text { and interdependencies } \\
\text { pivotal }\end{array}$ & $\begin{array}{l}\text { - Normative } \\
\text { expectations } \\
\text { — Past dispositions }\end{array}$ & $\begin{array}{l}\text { Diversity and inter- } \\
\text { relation }\end{array}$ \\
\hline \multirow{2}{*}{$\begin{array}{l}\text { Interactions among actors } \\
\text { affect network positions }\end{array}$} & — Local context & Ambiguity is tolerated \\
\hline & $\begin{array}{l}\text { An on-going recursive } \\
\text { process exists }\end{array}$ & $\begin{array}{l}\text { Collective mind needs } \\
\text { to be managed }\end{array}$ \\
\hline
\end{tabular}

activities for developing network insight. Network insight is understood as a network property, a structure as well as a process (Weick, 1988; Weick \& Roberts, 1993). The proposed frame is informed by the conceptual perspectives of network, knowledge, and collective mind. It is depicted as a funnel (see Fig. 1), and illustrates a process of amalgamating dispersed network pictures in a business network. The amalgamation process defines the mechanism of how the real, and subsequently the objectified view becomes apparent. It does not, however, occur instantly. There are a number of enablers and barriers to amalgamation of cognitive views and it is a timeconsuming process that needs to be managed.

Managers' cognitive views or 'pictures' can be described analytically as a) impressions, b) images and c) identities. Impressions include managerial expectations, such as the expected return on assets, expected performance or certain roles within a business network. They also include aspirations or concerns with regard to activities, i.e. programs of action. Images are framed by the sense-making of the business network and the extant knowledge the competitive commercial game. They are the managers' mental maps that reduce important network properties, logical links and rules into simple and manageable representations. Furthermore, identities refer to managers' self-perceptions and their sedimented experience from the past. However, network pictures of individual members of a management team are usually not enacted unilaterally and immediately but trigger an exchange process within and between companies. These network exchanges involve an on-going negotiation among actors. Normative expectations might clash, past dispositions might shape the interactions, and contextual variables will mediate the process. Often external data is used to 'validate' or 'falsify' certain aspects of shared elements of network pictures. Any synthesis reached at conclusion can still consist of many controversial elements within a shared understanding, e.g. based on misunderstandings, hidden agendas or perceptual opaqueness (Weick, 1990). Through this amalgamation process and the corresponding gain in clarity of sense-making, network insight is potentially created; thereby embedding some new options and possibilities for managing in networks. Possibilities are open to each organization through the comprehension of non-task related network properties. 'Insight', therefore, is not an individual interpretation that is inferred from a variety of cues; it is collective and objectified.

Our analysis of all these characteristics reveals three important enablers and barriers to the success of arriving at 'network insight' consisting of information, data and knowledge: firstly, the amalgamation process requires multilateral exchange; secondly, the amalgamation process is a managerial activity that is embedded in manifold rationalities and thirdly any amalgamation effort is time-consuming and simply not feasible without the efficacy of recursive time. Multilateral exchange, manifold rationality and recursive time are inherent complexities which impede the process of developing network insight. However, a better understanding of their characteristics, as well as how they impact on each other, can create a powerful platform of guiding managerial principles which could facilitate the whole amalgamation process. As such, the barriers to developing insight in business networks can also be seen as enablers if managed as part of the amalgamation process (see Fig. 2).

The operation of the three enablers/barriers to developing network insight is characterized by the following three concepts.

\subsection{Multilateral exchange}

Network insight is the amalgamated outcome of multiple negotiations and heedful interactions at numerous differing levels within and between organizations. A typical negotiation process will comprise several exchanges at regional as well as at headquarter levels, plus a plethora of related information gathering activities, often with third parties such as professional communities and public bodies. Consequential multilateral exchanges introduce complexity and lack of transparency into the interaction process which could be task specific as well as non-task specific. Managers' openness to move beyond existing task-specific exchanges and engage in heedful interactions is

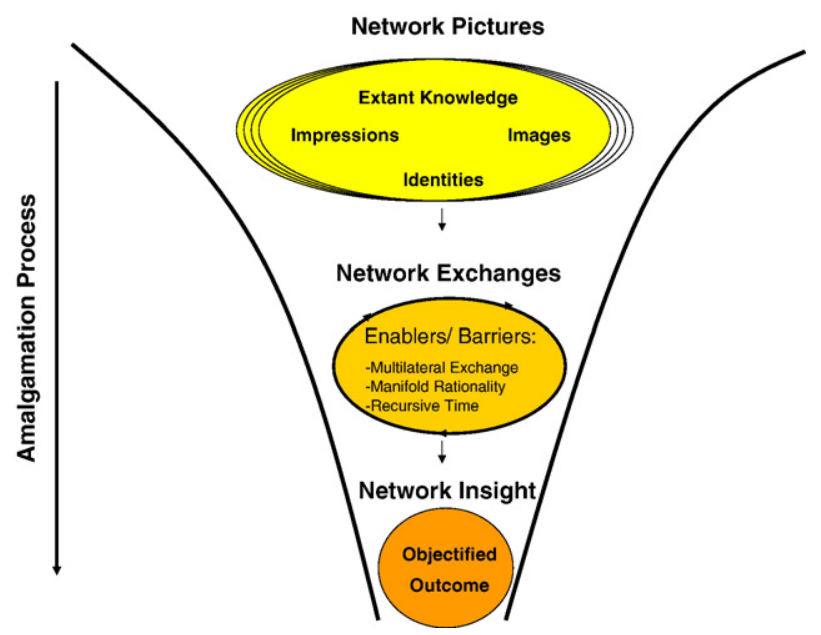

Fig. 1. Developing network insights. 


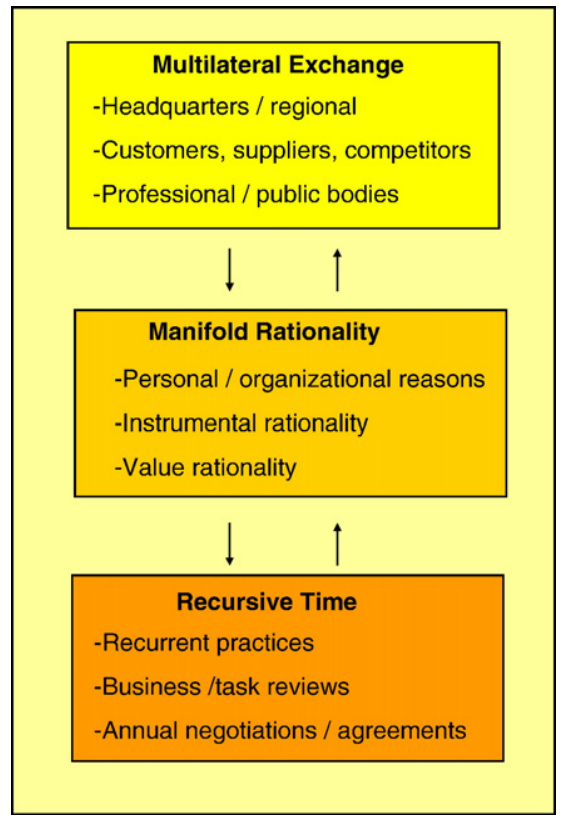

Fig. 2. Enablers/barriers to amalgamation process.

crucial for their ability to embrace new possibilities and develop alternative perspectives of their surrounding network. Furthermore, linking exchanges between levels as well as encouraging coordination will increase the 'heed' of these exchanges.

\subsection{Manifold rationality}

The creation of network insight is based on a manifold managerial logic. This logic is manifold in the sense that it emphasizes certain aspects that are important for individual managers and diverts attention from other facets which might be important for other managers in their surrounding networks. Moreover, individual managers might have personal reasons for doing things over and above what is 'right' for the organization (Webster \& Wind, 1972). A manifestation of manifold rationality can be found in the distinction between instrumental rationality ("Zweckrationalität") and value rationality ("Wertrationalität") as described by Weber (1956). According to Elster (2000), value rationality is guided by its consequences or end, whereas instrumental rationality is guided by means. Understanding and tolerating other managers' underlying logic is key to the process of effective exchanges in the network (Perrow, 1999) and thus key in developing network insight.

\subsection{Recursive time}

Network insight comprises an indeterminate outcome of recurrent business practices. Time is not understood as a linear process but as recursive practice. Organizational habits and institutionalized forms of interactions such as periodic business reviews, periodic task reviews, annual operating plans or annual negotiations or contractual agreements among firms are manifestations of recursive time. However, managers' time perspectives are often not aligned, although rigid exchange schedules may indicate the opposite. An example of the differences in the underlying expectations of actors (or actor groups) during exchanges has been provided by Snook (2000), in his analysis of different time expectations for deliberative processes between fighter pilots, AWACS flight controllers, and ground controllers. Therefore, managers need to understand the characteristics and the importance of time for other actors as well as the exchange process itself.

The result of managing the complexities of multilateral exchanges, manifold rationalities and recurrent practices is described as network insight. It is an objectified managerial outcome that includes "hard elements" which are measurable in terms of concrete deliverables for customers or unique methods, innovative practices or organizational procedures, as well as "soft elements" such as organizational learning and differential knowledge within a business network. Both hard and soft elements transcend the task-specific knowledge base of individual managerial cognitions. Thus, before discussing any guidelines for managing the process towards developing network insight, we will first proceed with testing this amalgamation process in two illustrative examples. The next sections will describe the applied methodology as well as the exemplifying cases.

\section{Research method}

This study is integral to an empirical investigation that started in September 2002 with the objective of identifying how companies mobilize other actors in their surrounding business network to work within the plans they develop. One of the most intriguing empirical findings of that research, articulated as the 'first challenge', demonstrated a considerable lack of network insight. We found that managers were preoccupied with their own tasks and concerns and were not always willing or able to develop a managerial capability to learn and mobilize other actors in their communities of practice, nor were they willing to engage in interactions that would result in common-held knowledge. Their 'network pictures' were consequently simplistically oriented towards immediate task satisfaction, allowing only a myopic view of the relevant business network, as well as the options available to them to penetrate into their cognitive maps. This was evident in the managers' limited awareness about their supplier's, customers' and other actors' existing concerns, and the lack of knowledge on available strategic options or the ignorance of where certain capabilities and resources reside in a wider business network.

During 2003 and 2004, we critically revisited the crosssectional empirical evidence in light of our main research target of understanding how and why organizations of different types develop or fail to develop network insight. The field work included seven companies and 44 in-depth interviews of senior managers with business managers, key account managers, purchasing managers, sales managers, marketing managers and corporate lawyers who participated in the initial research. Interviews with related organizations and actors (e.g. customers or suppliers) supplemented these findings within a network context that was defined around the relevant focal companies. In 
addition, a research workshop was organized with twelve managers from sales and purchasing, project management and general management, representing a variety of industries as well as some of the best known blue chip manufacturers that included consumer goods and pharmaceutical companies, producers of semiconductors and also service providers (telecommunication, grocery retailing, and water suppliers). Following the method of case study research (Easton, 1995; Eisenhardt, 1989; Halinen \& Törnoos, 2005; Pettigrew, 1990; Tsoukas, 1989; Yin, 2003a), the current enquiry was based on written and verbal replies, multiple sources of information and triangulation of data (Janesick, 1994; Yin, 2003a,b) in order to maintain a chain of evidence and develop converging lines of investigation. Field observations of interactions with managers, impromptu chats, social events (e.g. lunch, coffee breaks), meetings etc. were logged shortly after they occurred into a self devised field-tracking-system. These were entered into a 'chronological events list' and served as a filter/index to the wider set of observations. This was crucial in the selection of 'significant' situations, which were selected for closer examination and triangulation of primary data (Janesick, 1994). A field/personal diary was also periodically written to supplement the formal material gathered, and provided reflections on the research as a whole. Additional electronic documents received via email and pertaining to all aspects of the companies involved were retained for analysis. In addition, we made use of publicly available data relevant for the cases.

Using the conceptual tools a) multilateral exchange, b) manifold rationality, and c) recursive time, the analysis of empirical data involved critical examination, evaluation, categorization and recombination of findings. As such, we attempted to 'generalize' our findings by integrating several views and accounts of what happened. Whilst this does not overcome all the limitations of an interpretative research view, it safeguards against a purely subjective and focal companyoriented representation. Therefore, the aim of the analysis was to evaluate, test and determine the extent to which existing knowledge claims do, or do not, truly represent or correspond to the world (Hunt, 1976, 1983). Thus our goal in data analysis was to link the conceptual tools with the empirical observations. This link was established through several cycles, moving between theoretical ideas and data on business practices. In our analysis, the observed world of developing network insight is an open system in which events do not invariably follow a determined pattern; instead they are subject to underlying processes and activities. For this reason, we needed to engage in analytical experimentation to identify the generality of processes that produced the events which were experienced. However, we distinguish generality from recurrent regularities. Our generality is ascribed to the 'operation' of processes which produced the observed events. Processes operate as mechanisms which may "... act in their normal way even when expected regularities do not occur" (Tsoukas, 1989, p. 551). They are triggers that answer 'why' and 'how' certain events occur. For this reason, processes differ from the deterministic or stochastic association of events. Rather, they are necessary mechanisms of acting in a set of circumstances. We will now examine the circumstances of two exemplifying cases.

\section{Exemplifying case A: successes in developing network insight}

\subsection{SABMiller}

The growth of a small local brewery in South Africa into the substantial SABMiller that exists today must rank as an extraordinary success story in terms of international expansion; and provides an excellent example of a company working purposefully to develop its network insight.

South African Breweries started brewing Castle Lager in South Africa during 1895, and listed on the Johannesburg Stock Exchange in 1897. Almost a century later, in 1999, it moved its primary listing to the London Stock Exchange. Although international expansion dated back to 1910 with the formation of Rhodesian Breweries, it was only since the 1990s that the company has aggressively pursued international expansion. This was crowned by the formation of SABMiller in 2002, when SAB acquired $100 \%$ of Miller Brewing Company, then the second largest in America. The company now turns over some $\$ 15$ bn a year, distributes to over forty countries on all continents, and it ranks among the top three brewers in more than thirty countries. This has been achieved while operating in many markets characterized by downward pressure on prices, commoditising market places, and increases in global market share among the larger players.

Apart from the changing market conditions, there have been other impediments to the international expansion. This growth has been achieved sometimes against great odds. For example, although access to appropriate technology was seen as a potentially problematic issue in moving into the large Chinese market, it was noted that the company's managers "were accustomed to managing factories with unreliable energy sources, inconsistent supply and delivery of inputs, unskilled labour pools, and the use of older technology and plant infrastructure" (Everatt, 2000).

In seeking to move from being a minor player to a global force in the industry, the company was prepared to develop a realistic, fact-based understanding of the marketplace, breaking with accepted conventions in a number of ways. SABMiller's managers were prepared to move beyond their extant understanding of doing business and to redefine their past identity as members of a small local brewery in South Africa. As noted by the CEO Graham Mackay, "Global beer businesses were supposed to come from Europe or America, developing markets were supposed to be poor or unreliable investments, and a third-world business couldn't compete in the first world" (Mackay, 2005).

The company has managed to do this through a combination of developing a clear understanding of each new market that they entered, and also by amalgamating management practices when necessary. This included a systematic analysis of key performance indicators such as market shares, revenues and earnings in each country; an exercise which was rigorously repeated, and which built on gaining incremental experience and knowledge in terms of both content and process. It was done using a three-phased approach of (1) acquisition and 
establishing the footprint (2) consolidation and value achievement, and (3) leveraging positions and brands; (Clark, 2005) and by applying best practice in marketing across the different areas. Cognizant of the fact that there is a growing backlash against 'anti-social' products, the company has outstanding marketing and yet also actively addresses consumers' alcohol misuse. This is evidenced, for example, in a campaign in Southern Africa which was implemented under the slogan "Drink responsibly, Drive Responsibly, Live Responsibly"; by adhering to the 'Kompania Piwowarske' voluntary code in Poland, and the Miller Brewing Company's range of "Live Responsibly" activities in the USA.

It is this systematic approach, its focus on replication of marketing practices over time that has given the company its competitive strength. Marketing practices involved an active mobilization of other companies such as suppliers, advertising and promotion agencies as well as retailers. Regular and intensive exchange with other companies allowed SABMiller's managers to challenge their previous assumptions and to initiate and test new business propositions in form of pilot projects or test markets. SABMiller's managers thus started to develop a deep understanding about their suppliers' and customers' concerns and the available possibilities for action. It was through the interaction with other players that the three-phased approach was so effective. In addition, the company places great emphasis on both achieving measurable results — via metrics such as earnings per share, and earnings per hectolitre brewed; and also on making sure that the right teams are in place in different cultural settings, aided by diverse and frequent interactions at all organizational levels. By using this dual approach, it has managed to replicate its business model globally, yet also to manage things differently at the local level as and when required.

\subsection{Exemplifying case B: deficiencies in developing network insight}

\subsubsection{International utility company Aquarius ${ }^{3}$}

Aquarius is an international utility company, owned by two European waste disposal and utility conglomerates. Aquarius specializes in acquiring utility companies from those developing countries that want to privatize the sector. It was negotiating a deal with the government of M-Land (GoM) in South America. GoM invited tenders for the majority of shares in the newly-privatized company MUS (M-land Utility Supply) that runs the country's utility and waste services.

Aquarius submitted a bid as part of the tender without having a fact-based view of existing possibilities. Their business managers did not know how many other bidders were involved, and they also did not fully comprehend crucial elements of the underlying business plan which related to the willingness of certain actors, such as final consumers, to pay for some necessary infrastructure investments. A major aspect of this was

\footnotetext{
${ }^{3}$ Names of actors and countries have been sanitised due to confidentiality issues. Therefore, no reference is made to publicly available data in this case (in contrast with the SABMiller case). because this would allow an identification of the company.
}

their reluctance to interact not just with their specific negotiation partner (RB) but also other relevant actors. In fact, Aquarius was at this point primarily inward-focused and did not engage in interactions or exchanges that would enhance trust, information transparency, or clarify expectations within the relevant exchange network. The only insight that they gained early on (based on weak impressions gained mainly through written exchanges) was that the country's regulatory body (RB), their main exchange and negotiation partner, was in fact weak and followed the instructions of GoM. Any interactions at that early stage were purely task-centered, involving only specific managers from one hierarchy, driven by argument-based exchanges without fostering mutual trust. Face-to-face meetings were rare. Nonetheless, Aquarius was driven by specific normative expectations and past dispositions. Aquarius' managers felt the pressure from their parent institutions because their company had not completed a deal for 2 years. Therefore, their own identity as managers of a business unit was under threat if they could not clinch this deal. Interaction patterns were consequently focused on communicating with and 'managing' of their internal constituencies.

During the negotiations and the subsequent information gathering, it became eventually clear to Aquarius that they were the only serious bidder. However, the managers had started negotiations with a very lucrative offer to GoM regarding the amount of investments that they intended to undertake. According to their subsequent information regarding competitive offers (which were gathered in a piecemeal fashion and took time to be aggregated because they emanated from interactions on lower hierarchy levels), they had to decrease these investment promises. GoM constantly used the original numbers as a negotiation ploy. While this was relatively successful at the beginning, Aquarius realized midway through the negotiations that GoM could not pull out of the deal (however, Aquarius was in the same position). Eventually, the negotiation equilibrium accrued which 'oiled' the subsequent synthesis of the positions that they took to the negotiation table. This happened because by now a critical number of interactions had happened between the main negotiating partners which allowed the implicit expectations and the relative power positions to be gauged by either party. In the end, Aquarius got the deal; which was around threequarters of the overall shares.

However, it transpired that Aquarius' managers had not reached a satisfactory level of understanding of their surrounding network: further interactions with GoM, RB and also with other competitors caused Aquarius' managers to realize that they could have got the deal for considerably less money, as GoM urgently needed liquidity forms of cash because of the country's debt situation. They also realized that they did not have meaningful interactions with a number of crucial network actors: such as the final consumers. Dealing with this important network constituency at this late point in the deal for the first time caused Aquarius to gain new information. Consequently, it became clear that the underlying business model for the share valuation was totally skewed: Aquarius did not recover any investment costs from final consumers due to a militant unwillingness to pay. As a consequence, the new business 
hemorrhaged funds during its first year and re-negotiation was required. This time, Aquarius' managers had gained some additional contextual insight into the general situation, acquired through more frequent and often non-task related contacts with government officials. However, this was not 'planned' but resulted from the need for more direct interaction patterns due to the fact that all parties were now involved in the implementation phase of the project. The company was able to use threats of pulling out of the deal; which would have destabilized the government. It was 6 months before a general election, and GoM actually had not made the privatization deal public. Any revelations would have destroyed GoM's re-election chances. Consequently, Aquarius was able to negotiate better tariffs and investment conditions. Although the re-negotiation ended in a viable business model for both sides, the Aquarius director lost his job due to the way he managed the initial negotiations and the lack of interactions with relevant network constituencies.

\subsection{Case analyses}

The first exemplary case (SABMiller) describes successes in managing the amalgamation process, with interactions helping the focal company as well as other network partners to form overlapping expectations and knowledge, while the second case (Aquarius) demonstrates how an amalgamation process that may lead to network insight can be blocked. It is, therefore, useful to look at the operation of different enablers/barriers to amalgamation process and analyze the circumstances where extant knowledge remains, as well as the circumstances where extant knowledge is successfully enriched with new, appropriate information, data and knowledge, in such a way that managers can use it practically in their organization. Multilateral exchange, manifold rationality, and recursive time are three inherent complexities which may facilitate or impede the managerial process of developing network insight. Table 2 displays how these complexities are impacting on a number of concrete episodes in our cases.

Case A provides evidence that SABMiller fostered a multilateral exchange with diverse interactions at all organizational levels, with the acquisition and establishing the footprint, as well as with the systematic leveraging of positions and brands. Case B, on the other hand, shows that Aquarius engaged in protracted and suboptimal interactions with an overall unsatisfactory result in the initial stage. In terms of static elements, Aquarius' managers had a very simplistic initial network understanding. Notably, the motivation of crucial players, such as consumers, was not understood; furthermore, interactions did not happen across hierarchy levels and they were mainly taskdriven and impersonal. The first case, SABMiller, demonstrates that the company managed to embrace a manifold rationality that was characterized by a fact-based understanding, measurable results and the use of metrics (based on shared views of all network partners regarding their importance) which included multiple performance indicators such as market shares, earnings per share, and earnings per hectoliter brewed but also a number of socially responsible codes. The use of objectified metrics enabled SABMiller to embrace multiple rationalities and assess
Table 2

Managing the amalgamation process

\begin{tabular}{|c|c|c|}
\hline $\begin{array}{l}\text { Enablers/barriers } \\
\text { to amalgamation } \\
\text { process }\end{array}$ & $\begin{array}{l}\text { Case A: SABMiller } \\
\text { successes in developing } \\
\text { network insight }\end{array}$ & $\begin{array}{l}\text { Case B: Aquarius deficiencies in } \\
\text { developing network insight }\end{array}$ \\
\hline \multirow[t]{3}{*}{$\begin{array}{r}\text { Multilateral } \\
\text { exchange }\end{array}$} & $\begin{array}{l}\text { Diverse interactions at } \\
\text { all organizational levels }\end{array}$ & $\begin{array}{l}\text { Interactions were limited to } \\
\text { regulatory body (start phase). }\end{array}$ \\
\hline & $\begin{array}{l}\text { Acquisition and } \\
\text { establishing the footprint }\end{array}$ & $\begin{array}{l}\text { Exchanges were limited to } \\
\text { task requirements and same } \\
\text { hierarchy levels }\end{array}$ \\
\hline & $\begin{array}{l}\text { Leveraging positions } \\
\text { and brands }\end{array}$ & $\begin{array}{l}\text { Argument-based exchanges; } \\
\text { mostly via written } \\
\text { communication }\end{array}$ \\
\hline \multirow[t]{3}{*}{$\begin{array}{l}\text { Manifold } \\
\text { rationality }\end{array}$} & $\begin{array}{l}\text { Fact-based } \\
\text { understanding and } \\
\text { measurable results }\end{array}$ & $\begin{array}{l}\text { Constrained rationalities driven } \\
\text { by normative expectations and } \\
\text { past dispositions based on } \\
\text { internal interactions }\end{array}$ \\
\hline & $\begin{array}{l}\text { Use of metrics with } \\
\text { multiple performance } \\
\text { indicators }\end{array}$ & $\begin{array}{l}\text { Managers focused on their own } \\
\text { identities/rationalities }\end{array}$ \\
\hline & $\begin{array}{l}\text { Taking social } \\
\text { responsibility seriously }\end{array}$ & $\begin{array}{l}\text { Business model for the share } \\
\text { valuation was skewed because } \\
\text { of limited network picture }\end{array}$ \\
\hline \multirow[t]{4}{*}{ Recursive time } & Frequent interaction & $\begin{array}{l}\text { Lack of periodic business } \\
\text { reviews and interaction patterns } \\
\text { (pure outcome focus). }\end{array}$ \\
\hline & $\begin{array}{l}\text { Replication of business } \\
\text { model over time globally }\end{array}$ & $\begin{array}{l}\text { Re-negotiation started with one } \\
\text { year delay after new information } \\
\text { was gained in implementation } \\
\text { interactions }\end{array}$ \\
\hline & $\begin{array}{l}\text { Replication of best } \\
\text { practices }\end{array}$ & $\begin{array}{l}\text { Late, more frequent contacts } \\
\text { with government officials }\end{array}$ \\
\hline & $\begin{array}{l}\text { Consolidation and value } \\
\text { achievement over time }\end{array}$ & \\
\hline
\end{tabular}

their performance in relation to the performance of other actors and, thereby, elaborate a common understanding of the world. This 'common knowledge' (Grant, 1996; Grant \& BadenFuller, 2004) was not represented in one individual person but was 'collective' (Wiley, 1988; Weick \& Roberts, 1993) in the sense that it was shared across the network.

In comparison, the second case, Aquarius, demonstrates the existence of constrained rationalities which were driven by normative expectations and past dispositions. Aquarius' managers 'under-managed' their existing knowledge pool by focusing on their own extant knowledge. Several knowledge aspects became sedimented in their network pictures and they did not engage in extensive 'recursive activities' such as regular business reviews or on-going negotiations with other actors in the network. Hence, extant knowledge was never challenged. Expectations regarding Aquarius' performance by its stakeholders acted as barriers to intensified interactions and consequently inhibited the knowledge amalgamation process. This resulted in the managers' perception that a deal was needed to reaffirm their organizational identity. This meant that past dispositions (i.e. business models that had worked in previous negotiations) were used without testing them in interactions and negotiations and consequently were implemented without adapting them to the specific network situation at hand. Hence, knowledge aspects of local context were constantly neglected by the managers, who were 'inward' looking in their 
managerial emphasis instead of interacting with other network players' frequently over time, and so enrich their understanding of exchange system on which the deal was negotiated. While Aquarius' managers were blinkered by a 'given' mental model (previous success characteristics, initial understanding of network pictures) they pushed aside new, and often, puzzling contracting information (if they actually were able to gain these information at all) Instead, SABMiller's managers engaged in heedful and frequent interactions with other actors in their surrounding network. This allowed the successful replication of business models and best practices over time globally, despite the existence of local impediments. This is, for example, demonstrated in the company's entry into the large Chinese market. SABMiller's managers respected the inherent contextual circumstances and repeatedly focused on the consolidation and value realization over time. In contrast, Aquarius managers were forced to exhibit 'heed' in their interaction characteristics only in order to remedy the situation and make sense of the vast amount of contradictory data that evolved in the implementation phase (i.e. when it became clear that the business model was falling through). Consequently, in the second, renegotiation phase, Aquarius' managers were much more sensitive towards the local context, and had a better understanding of multilateral exchanges. They integrated and shared their insights freely with other network partners in order to find a common, objectified solution.

The cases demonstrate the need for managers in networks to move beyond their extant knowledge and access new, appropriate information, data and knowledge, and use it systematically in their business activities. The empirical findings show that the insight that is necessary for a single company to improve its performance and deliver products and services that are valued in the marketplace is not available in a concentrated form and certainly cannot be encapsulated entirely by a single actor (Becker, 2001; Hayek, 1945; Tsoukas, 1996). Increasingly the information, data and knowledge that a firm needs to draw upon is dispersed in many different organizations. This dispersion creates the need for managers to secure access to other interrelated actors and manage the process of producing network insight on an on-going basis via interactions and exchange activities. Furthermore, the two exemplifying cases provide evidence that the complexities of multilateral exchanges, manifold rationalities and recurrent practices provide a platform for the understanding of factual physical and social artifacts involved in this process; they are enablers and barriers to developing network insight (see Table 2).

\section{Conclusion}

Weick (1993) reminds us that “... organizations can be good at decision making and still falter. They falter because of deficient sense-making." (p. 636). Individual cognitive 'pictures' held by managers as sense-making representations are not sufficient to incorporate the contextual elements of managerial action and an incomplete knowledge of the context may lead to inappropriate action. Organizations need on a continual basis network insight expressed in fact-based information, data and knowledge and they need processes to develop this. Our illustrative cases demonstrate that the managerial process of integrating dispersed pieces of network pictures is a real challenge for any company; and that a better understanding of developing network insight can provide three significant advantages.

Firstly, moving out of the boundaries of rational, task-related actions, we can increase our understanding of actors' potentials and their perceived options. Our findings indicate that existing potentials do not come solely from the idiosyncratic capabilities of companies but are essentially derived from the firm's membership in networks of exchange relationships. This aspect becomes tremendously important when organizations enter new business networks where they have not operated before. To escape the narrow boundaries of rational, task-related actions, such as the task of a bid described in our Case B, managers need to move beyond their own extant knowledge (pictures) and open themselves by building new relationships and heedful interactions (exchanges).

Secondly, a wider managerial perspective that rests on the potential inherent in multilateral exchange, manifold rationality and recursive time helps us understand the essential role of interaction and negotiation to resolve conflicts in every aspect of business life (Bazerman \& Neale, 1992; Sebenius, 1992). It appears that managers are unable to fully construct and explain in advance different views held by other actors; but these views are dynamic and continually re-configured through the ongoing negotiations undertaken within networks of exchange relationships (Jehn, Northcraft, \& Neale, 1999). This underlines the importance of understanding the rationalities inherent in unarticulated interests of other actors, as well as the importance of institutionalizing business forms of frequent interactions through periodic business and task reviews. Without a sufficiently deep understanding of others' logic, and without the existence of recurrent organizational practices, managers will not be able to conduct multiple exchanges; and without comprehensive multilateral exchanges with other actors managers diminish their ability to embrace possibilities that exist in their surrounding business networks.

Thirdly, an understanding of the process of developing insight helps us to appreciate the creation of competitive advantage within a business network, as well as for the business network itself. By developing insight in business networks, managers gain clarity of sense-making. The created insight incorporates new ways and options for managing in networks of exchange relationships. These new potentials are not individual views that are inferred from a variety of cues. Instead, they are objectified and collective possibilities. Thus 'insight' is manifested in information, data and knowledge, in such a way that managers can use it practically in their organization for differential positioning and strategic action. Therefore, developing insight can lead to a better assessment of the appropriateness of managerial action.

Despite the relevance of developing network insight, our findings demonstrate a considerable lack of 'insight' by many organizations, be it in specific situations regarding clinching a deal, or in non-specific situations regarding an assessment of the driving forces within a network. The evidence hitherto is that 
managers face tremendous difficulties in integrating disperse pieces of specialized knowledge held by various actors in their surrounding business networks. However, by understanding the barriers to developing insight, managers can recognize that the process of amalgamating dispersed pieces of inherent possibilities is manageable.

\section{Managerial implications}

Managers need to understand that the process that ultimately leads to developing insight does not occur automatically but needs to be guided carefully. Network insight is linked to individual and collective 'action' (Tsoukas, 2000) which has to be 'heedful' (Weick \& Roberts, 1993). Therefore, based on our analysis of business cases, we propose a set of guiding principles which could be used in understanding, developing and improving insight in business networks. Managers and management teams could carry, champion and mediate the following set of guiding principles:

- Extant knowledge is an inherent trap that can be avoided. Managers' knowledge should be tested and improved through several layers of heedful interactions and exchanges within the organization and with different exchange partners.

- Exchanges need to take place at all possible levels, at regional units and at headquarters, internally between different departments and individuals as well as externally between organizations and other groups and public bodies. Cross-hierarchical information exchange is to be encouraged.

- Managers' openness to emerging business opportunities requires the inclusion of non-task related exchanges and the ability to embrace new possibilities. This is often linked to a non-task related understanding of contextual variables alien to the managers' cognitive 'pictures' in business networks.

- Managers' underlying raison d'être should not divert their attention from other rationales, motivations, and restrictions which might be important for other actors and organizations.

- Managers need to distinguish between value rationality guided by its consequences and instrumental rationality guided by its means. To do so, managers could move beyond assessing articulated issues and positions, and improve their understanding of other managers' underlying interests.

- Knowledge needs to become objectified in form of shared data and shared information so that it can be used practically for differentiating positioning. Individual knowledge or company-centered knowledge is not sufficient for exchange insights.

- The achievement of objectified knowledge requires more than mere search endeavors. It requires managers' subsequent action to test and codify what is feasible in their surrounding network. Examples of subsequent managerial action include pilot projects or test markets.

- Managers should think of time as recurrent practice of periodical business reviews, negotiation episodes or contractual agreements. These are resolutions that contribute to an incremental development of insight in business networks.
Following these guiding principles, managers' effort to find what is possible in their surrounding business networks becomes a way of life. It is an indeterminate managerial effort through multilateral interactions. Given the inherent difficulties involved in developing and sustaining this effort, managers need to grasp the challenge of developing insight in business networks seriously and guide the involved process heedfully.

\section{References}

Achrol, R. S. (1997). Changes in the theory of interorganizational relations in marketing: Toward a network paradigm. Journal of the Academy of Marketing Science, 25(1), 56-71.

Achrol, R. S., \& Kotler, P. (1999). Marketing in the network economy. Journal of Marketing, 63, 146-163 (Special).

Anderson, J. C., Håkansson, H., \& Johanson, J. (1994). Dyadic business relationships within a business network context. Journal of Marketing, 58, $1-15$.

Asch, S. E. (1952). Social psychology. Englewood: Prentice Hall.

Axelsson, B. (1992). Corporate strategy models and networks - diverging perspectives. In B. Axelsson \& G. Easton (Eds.), Industrial networks: A new view of reality (pp. 184-204). Routledge.

Bazerman, M., \& Neale, M. (1992). Negotiating rationally. New York: Free Press.

Becker, M. (2001). Managing dispersed knowledge: Organizational problems, managerial strategies and their effectiveness. Journal of Management Studies, 38(7), 1037-1051.

Beinhocker, E. D. (1999, Spring). Robust adaptive strategies. Sloan Management Review, 95-106.

Biggart, N. W., \& Delbridge, R. (2004). Systems of exchange. Academy of Management Review, 29(1), 28-49.

Bogner, W. C., \& Thomas, H. (1993). The role of competitive groups in strategy formulation: A dynamic integration of two competing models. Journal of Management Studies, 30(1), 51-67.

Boisot, M. (1995). Information space: A framework for learning in organizations, institutions and culture. London: Routledge.

Bougon, M. G. (1992). Congregate cognitive maps: A unified dynamic theory of organization and strategy. Journal of Management Studies, 29(3), 369-389.

Bougon, M. G., Weick, K., \& Binkhorst, D. (1977). Cognitions in organizations: An analysis of the Utrecht Jazz Orchestra. Administrative Quarterly, 22, 606-639.

de Chernatony, L., Daniels, K., \& Johnson, G. (1993). A cognitive perspective of manager's perceptions of competition. Journal of Marketing Management, 9, 373-381.

Clark, A. (2005). Building brands in Europe. Dr KW Beverage Conference, Madrid, 26 April. www.sabmiller.com

Cova, B., Mazet, F., \& Salle, R. (1998). From districts to Milieux: In search of network boundaries. In P. Naudé \& P. W. Turnbull (Eds.), Network dynamics in international marketing (pp. 195-210). Pergamon/Elsevier Science.

Czarniawska, B. (2004). On time, space, and action nets. Organization, 11(6), 773-791.

Daft, R. L., \& Weick, K. E. (1984). Toward a model of organizations as interpretation systems. Academy of Management Review, 9(2), 284-295.

Daniels, K., Johnson, G., \& de Chernatony, L. (2002). Task and institutional influences on managers' mental models of competition. Organization Studies, 23(1), 31-62.

Denrell, J., Fang, C., \& Winter, S. (2003). The economics of strategic opportunity. Strategic Management Journal, 24, 977-990.

Dyer, J. D., \& Singh, H. (1998). The relational view: Cooperative strategy and sources of interorganizational competitive advantage. Academy of Management Review, 23(4), 660-679.

Easton, G. (1992). Industrial networks: A review. In B. Axelsson \& G. Easton (Eds.), Industrial networks: A new view of reality (pp. 3-27). London: Routledge. 
Easton, G. (1995). Methodology and industrial networks. In K. Möller \& D. T. Wilson (Eds.), Business marketing: An interaction and network perspective (pp. 411-491). Norwell, MA: Kluwer Academic Publishing.

Easton, G., \& Håkansson, H. (1996). Markets as networks: Editorial introduction. International Journal of Research in Marketing, 13, 407-413.

Eden, C. (1989). Using cognitive mapping for strategic options development and analysis. In J. Rosenhead (Ed.), Rational analysis for a problematic world. Chicester: Wiley.

Eden, C., Ackermann, F., \& Cropper, S. (1992). The analysis of cause maps. Journal of Management Studies, 29(3), 309-324.

Eden, C., Jones, S., \& Sims, D. (1983). Messing about in problems. Oxford: Pergamon.

Eisenhardt, K. M. (1989). Building theories from case study research. Academy of Management Review, 14(4), 532-550.

Eisenhardt, K. M., \& Martin, J. A. (2000). Dynamic capabilities: What are they? Strategic Management Journal, 21, 1105-1121.

Elster, J. (2000). Rationality, economy and society. In S. P. Turner (Ed.), The Cambridge companion to Weber (pp. 21-41). Cambridge: Cambridge University Press.

Everatt, D. (2000). South African Breweries International: Devising a China Market Strategy. Richard Ivey School of Business, case study no. 9BOOA024.

Fiol, C. M., \& Huff, A. S. (1992). Maps for managers: Where are we? Where do we go from here? Journal of Management Studies, 29(3), 268-285.

Ford, D. (1998). Two decades of interaction, relationships and networks. In P Naudé \& P. W. Turnbull (Eds.), Network dynamics in international marketing (pp. 3-15). Pergamon/Elsevier Science.

Ford, D., Gadde, L. E., Hakansson, H., \& Snehota, I. (2003). Managing business networks. Chichester: John Wiley.

Ford, D., McDowell, R., \& Tomkins, C. (1998). Exploring relationship strategy. In P. Naudé \& P. W. Turnbull (Eds.), Network dynamics in international marketing (pp. 251-275). Pergamon/Elsevier Science.

Gadde, L. E., Huemer, L., \& Håkansson, H. (2003). Strategizing in industrial networks. Industrial Marketing Management, 32(5), 357-365.

Giddens, A. (1984). The constitution of society. Cambridge: Polity Press.

Gnyawali, D. R., \& Madhavan, R. (2001). Cooperative networks and competitive dynamics: Structural embeddedness perspective. Academy of Management Review, 26(3), 431-445.

Grant, R. M. (1996). Prospering in dynamically-competitive environments: Organisational capability as knowledge integration. Organization Science, 7(4), 375-387.

Grant, R. M., \& Baden-Fuller, C. (2004). A knowledge accessing theory of strategic alliances. Journal of Management Studies, 41(1), 61-84.

Håkansson, H., \& Ford, D. (2002). How should companies interact in business networks. Journal of Business Research, 55, 133-139.

Håkansson, H., \& Snehota, I. (1994). Analysing business relationships. In H. Håkansson \& I. Snehota (Eds.), Developing relationships in business networks (pp. 24-49). London: Routlegde.

Halinen, A., Salmi, A., \& Havila, V. (1999). From dyadic change to changing business networks: An analytical framework. Journal of Management Studies, 36(6), 779-795.

Halinen, A., \& Törnoos, J. A. (2005). Using case methods in the study of contemporary business networks. Journal of Business Research, 58, $1285-1297$.

Hargadon, A., \& Fanelli, A. (2002). Action and possibility: Reconciling dual perspectives of knowledge in organizations. Organization Science, 13(3), 290-302.

Hayek, F. A. (1945). The use of knowledge in society. American Economic Review, 35(4), 519-531.

Henneberg, S. C., Mouzas, S., \& Naudé, P. (2006). Network pictures - Concepts and representations. European Journal of Marketing, 40(3/4), 408-429.

Hodgkinson, G. P. (1997). The cognitive analysis of competitive structures: A review and critique. Human Relations, 50(6), 625-654.

Hodgkinson, G. P. (2001). Influence in marketing channels: A sense-making investigation. Psychology and Marketing, 18(5), 423-444.

Hodgkinson, G. P., \& Johnson, G. (1994). Exploring the mental maps of competitive strategists: The case for a processual approach. Journal of Management Studies, 31(4), 525-551.
Holmen, E., \& Pedersen, A. C. (2003). Strategizing through analyzing and influencing the network horizon. Industrial Marketing Management, 32(5), 409-418.

Huff, A. S. (1990). Mapping strategic thought. In A. S. Huff (Ed.), Mapping strategic thought (pp. 11-49). Chichester: Wiley.

Huff, A. S. (1997). A current and future agenda for cognitive research in organizations. Journal of Management Studies, 34(6), 947-952.

Hunt, S. D. (1976). The nature and scope of marketing. Journal of Marketing, $40,17-28$.

Hunt, S. D. (1983). General theories and the fundamental explananda of marketing. Journal of Marketing, 47, 9-17.

Hunt, S. D. (1990). Truth in marketing theory and research. Journal of Marketing, 54, 1-15.

Janesick, V. J. (1994). The dance of qualitative research design. In N. K. Denzin \& Y. S. Lincoln (Eds.), Handbook of qualitative research (pp. 209-219). Thousand Oaks: Sage.

Jeffcutt, P. (1994). The interpretation of organization: A contemporary analysis and critique. Journal of Management Studies, 31(2), 225-250.

Jehn, K. A., Northcraft, G. B., \& Neale, M. A. (1999). Why differences make a difference: A field study of diversity, conflict, and performance in workgroups. Administrative Science Quarterly, 44, 741-763.

Johnson, P., Daniels, K., \& Asch, R. (1998). Mental Models of Competition. In C. Eden \& J. -C. Spender (Eds.), Managerial and organizational cognition (pp. 130-146). London: Sage.

Johanson, J., \& Mattsson, L. G. (1992). Network positions and strategic action An analytic framework. In B. Axelsson \& G. Easton (Eds.), Industrial networks: A new view of reality (pp. 204-217). Routledge.

Karamanos, A. G. (2003). Complexity, identity and the value of knowledgeintensive exchanges. Journal of Management Studies, 40(7), 1871-1890.

Kranton, R. E., \& Minehart, D. F. (2001). A theory of buyer-seller networks. American Economic Review, 91(3), 485-509.

Luehman, T. A. (1998). Strategy as a portfolio of real options. Harvard Business Review, 32(2), 87-91.

Lyles, M. A., \& Schwenk, C. R. (1992). Top management, strategy and organizational knowledge structures. Journal of Management Studies, 29(2), $155-174$.

Mackay, G. (2005). Challenging Conventional Wisdom in the Global Beer Business, speaking in Milwaukee, US, 14 April. www.sabmiller.com [accessed 30/6/2005].

March, J. G. \& Olsen, J. P. (Eds.). (1989). Rediscovering organizations: The organizational basis of politics. New York: Free Press.

March, J. G., \& Simon, H. A. (1993). Organizations (2nd edition). Blackwell 1st Edition 1958

Mattsson, L. -G. (2002a). Dynamics of Markets: How 'Actor-Network Theory' and 'Markets-as-Networks' can Learn From Each Other, Paper presented at the Nordic Workshop on Interorganizational Studies, August 2002, Kolding.

Mattsson, L. -G. (2002b). Reorganization of Distribution in Globalisation of Markets, Keynote Paper presented at the 18th IMP Conference, Dec. 2002, Perth.

Mattsson, L. -G. (2003). Understanding Market Dynamics - Potential Contributions to Market(ing). Studies from Actor-Network-Theory, Paper presented at the 19th IMP Conference, Sept. 2003, Lugano.

McGrath, R. G., Ferrier, W., \& Mendelow, A. (2004). Real options as engines of choice and heterogeneity. Academy of Management Review, 29(1), $102-110$

McLoughlin, D., \& Horan, C. (2000). Business marketing: Perspectives from the markets-as-networks approach. Industrial Marketing Management, 29, 285-292.

McNamara, G., Deephouse, D., \& Luce, R. A. (2003). Competitive Positioning Within and Across Strategic Group Structure. Strategic Management Journal, 24(2), 161-182.

McNamara, G., Luce, R. A., \& Tompson, G. H. (2002). Examining the effect of complexity in strategic group knowledge structures on firm performance. Strategic Management Journal, 23(3), 221-235.

Meindl, J. R., Stubbart, C., \& Porac, J. F. (1994). Cognition within and between organizations: Five key questions. Organization Science, 5(3), 289-293.

Mintzberg, H. (1979). An emerging strategy of "direct" research. Administrative Science Quarterly, 24, 582-589. 
Mintzberg, H., \& Waters, J. A. (1985). Of strategies, deliberate and emergent. Strategic Management Journal, 6(3), 257-272.

Möller, K. K., \& Halinen, A. (1999). Business relationships and networks: Managerial challenge of network era. Industrial Marketing Management, $28,413-427$.

Osborne, J. D., Stubbart, C. I., \& Ramaprasad, A. (2001). Strategic groups and competitive enactment: A study of dynamic relationships between mental models and performance. Strategic Management Journal, 22, 435-454.

Perrow, C. (1999). Normal accidents. Princeton: Princeton University Press.

Pettigrew, A. M. (1990). Longitudinal field research on change: Theory and practice. Organization Science, 1(3), 267-292.

Porac, J. F., Thomas, H., \& Baden-Fuller, C. (1989). Competitive groups as cognitive communities: The case of Scottish Knitwear Manufacturers. Journal of Management Studies, 26(4), 397-416.

Radner, R. (1996). Bounded rationality, indeterminancy, and the theory of the firm. The Economic Journal, 106, 1360-1373.

Ring, P. S., \& van de Ven, A. H. (1994). Developmental processes of cooperative interorganizational relationships. Academy of Management Review, 19, 90-118.

Ritter, T. (1999). The networking company. Industrial Marketing Management, $28,467-479$

Ritter, T. (2000). A framework for analyzing interconnectedness of relationships. Industrial Marketing Management, 29(4), 317-327.

Ritter, T., Wilkinson, I. F., \& Johnston, W. J. (2002). Measuring network competence: Some international evidence. Journal of Business and Industrial Marketing, 17(2/3), 119-138.

Ryle, G. (1949). The concept of mind. Chicago: Chicago University Press.

Sabel, C. (1994). Learning by monitoring: The institutions of economic development. In N. L. Smelser \& R. Swedberg (Eds.), The handbook of economic sociology Princeton, N.J: Princeton University Press.

Sayer, A. (1984). Method in social science. London: Routledge.

Sebenius, J. K. (1992). Negotiation analysis: A characterization and review. Management Science, 38(1), 18-38.

Simon, H. A. (1976). Administrative behavior. New York: Macmillan.

Simon, H. A. (1979). Rational decision making in business organizations. The American Economic Review, 69(4), 493-513.

Simon, H. A. (1991). Bounded rationality and organizational learning. Organization Science, 2(1), 125-134.

Simon, H. (1997). Models of bounded rationality. Empirically grounded economic reason, Vol. 3. Boston: MIT Press.

Smircich, L., \& Stubbart, C. (1985). Strategic management in an enacted world. Academy of Management Review, 10(4), 724-738.

Snook, S. (2000). Friendly fire. Princeton: Princeton University Press.

Spender, J. C. (1998). The Dynamics of Individual and Organizational Knowledge. In C. Eden \& J. -C. Spender (Eds.), Managerial and organizational cognition (pp. 13-39). London: Sage.

Stevenson, W. B., \& Greenberg, D. (2000). Agency and social networks: Strategies of action in a social structure of position, opposition and opportunity. Administrative Science Quarterly, 45, 651-678.

Stubbart, C. I. (1989). Managerial cognition: A missing link in strategic management research. Journal of Management Studies, 26(4), 325-347.

Tsoukas, H. (1989). The validity of idiographic research explanations. Academy of Management Review, 14(4), 551-561.

Tsoukas, H. (1996). The firm as a distributed knowledge system: A constructionist approach. Strategic Management Journal, 17, 11-25.

Tsoukas, H. (2000). Knowledge as action, organization as theory. Emergence, 2(4), 112-204.

Turnbull, P., Ford, D., \& Cunningham, M. (1996). Interaction, relationships and networks in business markets: An evolving perspective. Journal of Business and Industrial Marketing, 11(3/4), 44-62.
Uzzi, B. (1997). Social structure and competition in interfirm networks: The paradox of embeddedness. Administrative Science Quarterly, 42(1), $37-70$.

Uzzi, B., \& Lancaster, R. (2003). Embeddedness and learning: The case of bank loan managers and their clients. Management Science, 49(4), 383-400.

Weber, M. (1956). Wirtschaft und Gesellschaft, 2 Bände, J.C.B.Mohr. Tübingen: Paul Siebeck Verlag.

Webster, F. E., \& Wind, Y. (1972). A general model for understanding organizational buying behavior. Journal of Marketing, 36, 12-19.

Weick, K. E. (1979). The social psychology of organizing. Reading: AddisonWesley.

Weick, K. E. (1988). Enacted sensemaking in crisis situations. Journal of Management Studies, 25(4), 305-317.

Weick, K. E. (1990). The vulnerable system: An analysis of the Tenerife air disaster. Journal of Management, 16(3), 571-593.

Weick, K. E. (1993). The collapse of sensemaking in the organizations: The Mann Gulch disaster. Administrative Science Quarterly, 38, 628-652.

Weick, K. E. (1995). Sensemaking in organizations. Thousand Oaks: Sage.

Weick, K. E., \& Roberts, K. H. (1993). Collective mind in organizations: Heedful interrelating on flight decks. Administrative Science Quarterly, 38, $357-381$.

Wiley, N. (1988). The micro-macro problem in social theory. Sociological Theory, 6, 254-261.

Wilkinson, I., \& Young, L. (2002). On cooperating - Firms, relations and networks. Journal of Business Research, 55, 123-132.

Williamson, P. J. (1999). Strategy as options on the future. Sloan Management Review, 40(3), 117-126.

Witt, U. (2000). Changing cognitive frames - Changing organizational forms: An entrepreneurial theory of organizational development. Industrial and Corporate Change, 9(4), 733-755.

Yin, R. K. (2003a). Case study research. Thousand Oaks: Sage.

Yin, R. K. (2003b). Applications of case study research. Thousand Oaks: Sage.

Stefanos Mouzas is a Senior Lecturer in Marketing at Lancaster University, School of Management, UK. He received his PhD in Marketing from Lancaster University, School of Management. His publications and research interests lie in the area of inter-firm negotiations and deal making. He published on negotiation and deal-making in the Journal of Business Research, Negotiation Journal, European Journal of Marketing, Journal of Business and Industrial Marketing, and Industrial Marketing Management.

Stephan C. Henneberg is Senior Lecturer in Marketing at Manchester Business School, University of Manchester, UK. He obtained his $\mathrm{PhD}$ in Marketing from the University of Cambridge, Judge Business School. His current research interests are in the areas of strategic marketing, relational marketing, consumer behavior, strategic competences, and social and political marketing. He has published on issues of network marketing in the European Journal of Marketing, Journal of Marketing Management, Journal of Relationship Marketing, and Industrial Marketing Management.

Peter Naudé is Professor of Marketing at Manchester Business School, University of Manchester, UK. He gained his $\mathrm{PhD}$ in Marketing from the University of Manchester. His research interests are in quantitative modeling and B2B Marketing. He published in the Industrial Marketing Management, European Journal of Marketing, Journal of Business and Industrial Marketing, and Journal of Business-to-Business Marketing. 